ART IN GENERAL EDUCATION, 1870-1900:

THE INTRODUCTION OF THREE-DIMENSIONAL ART REPRODUCTIONS

INTO THE PUBLIC SCHOOLS OF THE UNITED STATES

\title{
James McNutt
}

\section{Introduction}

In 1868 a special committee was appointed by the American Social Association in Boston to consider the question of "How to promote a better taste among our people" (Committee Report, 1869, p. 151). The committee, after much deliberation, adopted a plan to place

... in some public school of our larger cities,

fac-simile plaster casts of the works selected, not as

models for drawing only, but as a means of developing,

through the constant contemplation of types of perfect

beauty, a better taste, in general, among the rising

generation. (p. 151)

A collection of plaster casts was selected by the committee because of their availability, cheapness, and "... a simple but efficient means of introducing an aesthetic element into the education system of the United States" (Committee Report, 1871, p. 202).

The efforts of the committee were accomplished in 1870. At that time, twenty-two plaster casts of "antique" sculptures were placed in the High School and Normal School for Girls on West Newton Street in Boston. This newly constructed school in Boston was chosen because of the character of the building and comprised ". . . just that body of teachers and pupils with whom the experiment might be most favorably tried (p. 202).

Charles C. Perkins, a member of the school board of Boston from 1870 to 1883 (White, 1897 , p. 524), was confident in this decision. According to Perkins (1871), "This effort to influence the taste of 
the rising generation is a move in the right direction, which cannot fail to be initiated elsewhere" (p. 96).

The idea of placing reproductions into the public schools did disseminate to other parts of the country. According to Herbert B. Adams (1901), by 1899 this "educational movement" had spread throughout the Northern and Western States (p. 344).

This historical study is concerned with the first attempt by eductors in 1870 to expand the art curriculum beyond the making of art. This expansion of the art curriculum was contingent on the introduction of reproductions into the public schools. Since plaster casts were the first official reproductions to be placed into a public school, the study will focus on:

1. The introduction of plaster casts into the United States. This information could be of value to better understand the ideas, beliefs, and customs of the people responsible for the introduction of plaster casts into the public schools.

2. The introduction of plaster casts into the public schools between 1870 and 1900. As the study develops, some attention may need to be given to the placement and use of other types of art reproductions. This would include reproductions of drawings and paintings, which may have been introduced into some public schools as the movement spread to other parts of the country from 1870 to 1900.

3. Any social and educational factor which may have influenced the aims and purposes of this "educational movement" between 1870 and 1900 .

This study will be based on primary and secondary sources. The greatest reliance for evidence, however, will be placed on primary sources - newspapers, periodicals, and government reports published between 1870 and 1900. External and internal critical techniques will be utilized in the evaluation of both the primary and secondary 
sources.

\section{Problem Statement}

For almost a quarter of a century, contemporary art educators have expressed a concern that the art curriculum in the public schools should include the domains of art production, art history, and art criticism (Barkan, 1962; Barkan, 1966; Hubbard, 1967; Eisner, 1972; Chapman, 1978; the National Art Educational Association, 1968; and the National Assessment of Educational Progress, 1981). The most current view of the art curriculum is that attention be given "to the disciplines that contribute to understanding art: art production, art history, art criticism, and aesthetics" (Getty Report, 1984, p. v).

Each of these art domains or disciplines require (to some extent) the use of visual art forms for instructional purposes. The classroom teacher can accomplish this by either acquainting the student with original works of art, reproductions of art, or both. According to Banfield (1982), there is a belief among professionals in the visual arts that reproductions cannot possibly have the aesthetic value of an original (p. 145). In most classroom situations, however, the use of reproductions of works of art (in one form or other) is the most practical and convenient method to study visual art forms created by the professional artist.

The first attempt to add an "aesthetic element into the educational system of the United States" (Committee Report, 1871, p. 202) was accomplished in 1870 when plaster casts were placed in a public school. The published histories, textbooks, reports, articles, and unpublished dissertations that document the history of art education between 1870 and 1900 have a tendency to minimize or ignore this effort (Logan, 1955; Wygant, 1983; Haney, 1908; Whitford, 1936; Barkan, 1955; Munro, 1956; de Francesco, 1958; Gaitskell, 1958; Hubbard, 1967; Eisner, 1972; Chapman, 1978; Saunders, 1966; Stankiewicz, 1984; and Belshe, 1946). 
Contemporary approaches to teaching art production, art history, art criticism, and aesthetics depend on the use of art reproductions. Although art reproductions figure prominently in teaching methodology, there is a dearth of knowledge in the published history of art education of any changes in ideas, values, beliefs, and attitudes that motivated human behavior in relation to the placement of reproductions into the public schools between 1870 and 1900. As a result, there is no clear understanding of the significance of this movement in relation to the formative years of art education in the United States.

\section{Purpose of this Study}

The purpose of this study is to determine the historical significance of the placement of art reproductions into the public schools of the United States between 1870 and 1900. In order to determine the significance of this movement, the research will attempt to answer the following questions:

1. When were reproductions, plaster casts in particular, introduced into the United States?

2. Why were reproductions introduced into the United States?

3. Why were plaster casts, other than availability and cheapness, selected as the first reproductions to be placed into a public school?

4. What ideals, values, beliefs, and attitudes toward plaster casts influenced the individuals responsible for this action in 1870 ?

5. What social and educational factors influenced the spread of this movement to other parts of the United States?

6. Were different types of reproductions, other than plaster casts of "antique sculpture," introduced into schools as the movement spread to different parts of the country?

7. What educational aims and purposes did different individuals perceive as the value of placing art reproductions into 
schools?

8. What was the relationship, if any, between this movement in the public schools and the development of art museums?

9. What influence did this movement have on future developments in art education?

\section{Significance of the Study}

Between 1865 and 1915 the United States recovered from a disastrous Civil War and moved from an agricultural society to a leading industrial world power (Butts and Cremin, 1953, p. 293). In 1870, five years after the end of the Civil War and at the beginning of the industrial revolution, plaster casts were introduced into a public school. This movement, over the next thirty years, spread to other parts of the country.

A detailed study of this movement should contribute to a better understanding of the role that art reproductions, specifically plaster casts, played in the art education of this changing society. This understanding will be based on the ideas, values, beliefs, and attitudes of the individuals responsible for this action and the changing social conditions that influenced them.

\section{The Approach}

A chronological approach to history in combination with a cultural approach will be used to synthesize the historical facts. The chronological approach will be of value for the organization of this educational movement from 1870 to 1900 . The cultural approach will be used to interpret the relationship between art, education, and society during this time period.

\section{References}

Adams, H. B. (1901). Art decoration in the public schools. Education

Report, 1899-1900. Washington: Government Printing Office. 
Banfield, E. C. (1984). The democratic muse. New York: Basic Books, Inc.

Barkan, M. (1955). A foundation for art education. New York: Ronald Press.

Barkan, M. (1962). Transition in art education. Art Education, 15 (5), 12-18.

Barkan, M. (1966). Curriculum problems in art. In E. L. Mattil

(Ed.), A Seminar in Art Education for Research and Curriculum

Development (USOE Cooperative Research Project No. V-002)

(University Park: Pennsylvania State University) (pp. 240-256).

Belshe, F. B. (1946). A history of art education in the public schools of the United States. Unpublished doctoral dissertation, Yale University, New Haven, Conn.

Butts, R. F. and Cremin, L. A. (1953). A history of education in American culture. New York: Holt, Rinehart and Winston.

Chapman, L. H. (1978). Approaches to art in education. New York:

Harcourt Brace Jovanovich, Inc.

Committee Report (1869). Art in education. Journal of Social Science. (1), 151-152.

Committee Report (1871). Collection of casts. Journal of Social Science, (III), 202-206.

de Francesco, I. L. (1958). Art education, its means and ends. New York: Harper and Brothers.

Eisner, E. W. (1972). Educating artistic vision. New York: The MacMillan Company.

Gaitskell, C. D. (1958). Children and their art. New York:

Harcourt, Brace and Company.

Getty Report (1985). Beyond creating: The place for art in America's schools. The J. Paul Getty Trust.

Haney, J. P. (1908). Art education in the public schools of the

United States. New York: American Art Annual.

Hubbard, G. (1967). Art in the high school. California: Wadsworth 
Publishing Company.

Logan, F. M. (1955). Growth of art in American schools. New York:

Harper and Brothers.

Munro, T. (1956). Art education, its philosophy and psychology. New

York: Liberal Arts Press.

National Art Association. (1968). Policy statement. Art Education.

1 (1), pp. 30-32.

National Assessment of Educational Progress (1981). Art and young

Americans, 1974-1979: Results from the second national art

assessment. Report No. 10-A-01, Denver, Colorado.

Perkins, C. C. (1871). Art schools. Journal of Social Science. (IV), pp. 95-104.

Saunders, R. J. (1966). A history of the teaching of art appreciation in the public schools. In D. Ecker (Ed.) Improving the Teaching of Art Appreciation, U.S. Office of Education Cooperative Research Project V-006, Columbus: Ohio State University, 1-47. Stankiewicz, M. A. (1984). "The eye is a nobler organ": Ruskin and American art education. Journal of Aesthetic Education, 18 (2), 51-64.

The national cyclopedia of American biography, IV (1987)。 New York: James T. White and Co.

Whitford, W. (1936). An introduction to art education. New York: Appleton and Company.

Wygant, F. (1983). Art in American schools in the nineteenth century. Cincinnati: Interwood Press. 